\title{
Impaired lignocaine metabolism in patients with myocardial infarction and cardiac failure
}

\author{
L F PRESCOTT, K K ADJEPON-YAMOAH, R G TALBOT
}

British Medical fournal, 1976, 1, 939-941

\begin{abstract}
Summary
Plasma concentrations of lignocaine were measured during and after infusion of lignocaine at $1.4 \mathrm{mg} / \mathrm{min}$ for 36-46 hours in 12 patients with myocardial infarction and one patient with cardiac failure due to uncontrolled ventricular tachycardia. In six patients without cardiac failure the plasma concentrations of lignocaine rose progressively during the infusion and the mean lignocaine half life was 4.3 hours compared with 1.4 hours in healthy subjects. Mean plasma lignocaine concentrations were significantly higher in seven patients with cardiac failure, and concentrations also rose during the infusion and the half life was considerably prolonged to $10 \cdot 2$ hours. Lignocaine concentrations rose rapidly to toxic levels when cardiogenic shock developed in one patient and did not fall when the infusion was stopped. The mean plasma antipyrine half life was moderately prolonged (19.4 hours) in a larger group of patients with myocardial infarction and cardiac failure but returned to normal during convalescence (13.2 hours). The metabolism of lignocaine is grossly abnormal in patients with cardiac failure and cardiogenic shock after myocardial infarction.
\end{abstract}

\section{Introduction}

Patients who are ill may respond abnormally to drugs for various reasons. For example, the sensitivity of receptors to drugs may be influenced by disease and there may be changes in the concentrations of active drug at the sites of action as a result of abnormal drug absorption, distribution, or elimination. ${ }^{1}$ Such changes in response to a drug are particularly important in critically ill patients and when there is a narrow margin between

Departments of Therapeutics and Cardiology, Royal Infirmary, Edinburgh EH3 9YW

L F PRESCOTT, MD, FRCP ED, reader in clinical pharmacology and consultant physician

K K ADJEPON-YAMOAH, MRCP, research fellow in clinical pharmacology R G TALBOT, MRCP, research fellow in cardiology effective and toxic doses. Cardiac failure is a common condition in which drug disposition may be altered by a reduction in the volume of drug distribution and abnormally slow elimination as a result of reduced hepatic and renal blood flow. ${ }^{2}{ }^{3}$ Thus for a given dose drug concentrations may be higher in patients with cardiac failure and therefore present an increased risk of toxicity.

Lignocaine is widely used in treating acute ventricular arrhythmias in patients with myocardial infarction, who often have cardiac failure as a complication. The effects of lignocaine are related to plasma concentrations: the therapeutic range is thought to be $1.5-5 \mu \mathrm{g} / \mathrm{ml}$ and the risk of toxicity increases as concentrations rise above $5 \mu \mathrm{g} / \mathrm{ml}$. In some short-term studies plasma concentrations were found to be increased in patients with cardiac failure,,$^{2}$ and the metabolic clearance of lignocaine is significantly reduced in patients with myocardial infarction even in the absence of cardiac failure." Ethylglycylxylidide (EGX) and glycylxylidide (GX) are pharmacologically active metabolites of lignocaine which may also have to be taken into account since they have been suspected of causing toxicity. ${ }^{6}{ }^{7}$

We measured the plasma concentrations and urinary excretion of lignocaine, EGX, GX, and 4-hydroxyxylidine (an inactive metabolite) during and after prolonged infusion in patients in the coronary care unit to assess the effects of myocardial infarction and cardiac failure on lignocaine metabolism. Drug metabolising capacity was also assessed independently in a larger group of patients by measuring the plasma antipyrine half life.

\section{Patients and methods}

\section{LIGNOCAINE}

Lignocaine metabolism was studied in detail in 13 consenting male patients admitted to the coronary care unit of the Royal Infirmary, Edinburgh. All but one had myocardial infarction with ventricular arrhythmias that required treatment with lignocaine. ${ }^{*}$ The other patient (case 9) had cardiac failure due to uncontrolled ventricular tachycardia without evidence of infarction. Seven patients had cardiac failure of acute onset with dyspnoea, raised jugular venous pressure, basal crepitations, or radiological evidence of pulmonary oedema; one of these developed severe cardiogenic shock 25 hours after admission and died 24 hours later. There was no clinical evidence of cardiac failure in the remaining six patients. The patients with cardiac failure were older, weighed less $(P<0 \cdot 025)$, and had lower creatine phosphokinase $(\mathrm{CPK})$ levels than those without failure (table $\mathrm{I}$ ).

TABLE I-Clinical details of patients receiving lignocaine. Means ( $\pm S E$ of mean) for patients without and with cardiac failure are shown

\begin{tabular}{|c|c|c|c|c|c|c|c|c|}
\hline $\begin{array}{l}\text { Case } \\
\text { No }\end{array}$ & & $\begin{array}{l}\text { Age } \\
\text { (years) }\end{array}$ & & $\begin{array}{l}\text { Weight } \\
\text { (kg) }\end{array}$ & $\begin{array}{l}\text { Cardiac } \\
\text { failure }\end{array}$ & $\begin{array}{l}\text { Seru } \\
\text { phos }\end{array}$ & $\begin{array}{l}\text { Im creatine } \\
\text { sphokinase } \\
(\mathbf{I U} / \mathbf{l})\end{array}$ & $\begin{array}{l}\text { Drug treatment in } \\
\text { coronary care unit }\end{array}$ \\
\hline $\begin{array}{r}1 \\
2 \\
3 \\
4 \\
5 \\
6 \\
7 \\
8 \\
9 \\
10 \\
11 \\
12 \\
13\end{array}$ & $\left.\begin{array}{l}41 \\
57 \\
41 \\
42 \\
63 \\
56 \\
42 \\
57 \\
76 \\
59 \\
66 \\
68 \\
62\end{array}\right\}$ & $\begin{array}{l}50 \cdot 0 \pm 4 \cdot 0 \\
.61 \cdot 4 \pm 12 \cdot 7\end{array}$ & $\left.\begin{array}{l}95 \\
82 \\
79 \\
70 \\
76 \\
65 \\
57 \\
65 \\
73 \\
70 \\
83 \\
67\end{array}\right\}$ & $80 \cdot 4 \pm 4 \cdot 2$ & $\begin{array}{l}\text { No } \\
\text { No } \\
\text { No } \\
\text { No } \\
\text { No } \\
\text { No } \\
\text { Yes* } \\
\text { Yes } \\
\text { Yes† } \\
\text { Yes } \\
\text { Yes } \\
\text { Yes } \\
\text { Yes }\end{array}$ & $\left.\begin{array}{r}1540 \\
1710 \\
3200 \\
1360 \\
880 \\
1020 \\
1040 \\
460 \\
279 \\
1440 \\
364 \\
2000\end{array}\right\}$ & $\begin{array}{l}1618 \pm 342 \\
931 \pm 283\end{array}$ & $\begin{array}{l}\text { Diuretic, diazepam } \\
\text { Digoxin, procainamide, diazepam } \\
\text { Diuretic, dizaepam } \\
\text { Atropine, ampicillin, trifluoperazine } \\
\text { Procainamide, diazepam } \\
\text { Digoxin, diuretic, ampicillin, practolol } \\
\text { Procainamide, diazepam, diuretic } \\
\text { Digoxin, practolol, diuretic } \\
\text { Digoxin, diuretic } \\
\text { Digoxin, diazepam, diuretic, ampicillin } \\
\text { Digoxin, diuretic, diazepam } \\
\text { Diuretic, ampicillin, atropine }\end{array}$ \\
\hline
\end{tabular}

*Developed cardiogenic shock. †Ventricular tachycardia without myocardial infarction. 
Chest radiography, electrocardiography, liver function tests, and estimations of plasma urea, electrolytes, and CPK were performed daily. All patients were given warfarin, nitrazepam, morphine, and cyclizine; other drugs administered are shown in table I. Previous drug treatment included thyroxine (case 9), warfarin (case 8), and barbiturates (cases 8 and 12).

An initial intravenous bolus injection of $100 \mathrm{mg}$ of lignocaine hydrochloride was followed by constant infusion of lignocaine for 36-46 hours at a rate of $1.4 \mathrm{mg} / \mathrm{min}$ using a Braun pump. In case 9 the infusion rate was $1.3 \mathrm{mg} / \mathrm{min}$, and another patient (case 12) received two additional bolus injections of $100 \mathrm{mg}$ of lignocaine hydrochloride 24 hours after starting the infusion. Venous blood was taken from the opposite arm every eight hours during the infusion and at $0,1,2,4,6,8,12$, and 24 hours after it was discontinued. All urine was collected for six days and the volume and $\mathrm{pH}$ recorded. Plasma and aliquots of urine were stored frozen until assayed for lignocaine, EGX, GX, and 4-hydroxyxylidine by gas-liquid chromatography using a nitrogen-sensitive flame ionisation detector. ${ }^{9}$

\section{ANTIPYRINE}

The plasma antipyrine half life was measured in six patients (cases 8-13) and an additional eight patients with and nine patients without cardiac failure after myocardial infarction. In the combined groups the mean ages ( \pm SE of mean) of those with cardiac failure and those without were $61.3 \pm 1.9$ and $50.2 \pm 2.6$ years respectively; five patients were women. On the morning of the second day in the coronary care unit the fasting patients ingested $18 \mathrm{mg} / \mathrm{kg}$ of antipyrine dissolved in $50 \mathrm{ml}$ of orange juice, and serial blood samples were taken for 24-48 hours for estimating plasma antipyrine by gas-liquid chromatography. ${ }^{10}$ In 18 patients the study was repeated at least 10 days later during convalescence. With two exceptions, none of these patients had been given drugs known to induce hepatic microsomal enzymes.

Drug half life values were calculated from the linear plot of the logarithms of the plasma concentrations against time using the method of least squares. The apparent volume of antipyrine distribution was obtained by dividing the administered dose by the plasma concentration at zero time extrapolated from the graph.

\section{Results}

\section{PLASMA LIGNOCAINF}

The mean plasma lignocaine concentrations were significantly higher in the patients with cardiac failure than in those without at all times during and after the infusions $(P<0.01$, fig 1$)$, and the mean concentrations at the end of the infusion were $4 \cdot 1$ and $2.8 \mu \mathrm{g} / \mathrm{ml}$ respectively. In addition, uniform "steady state" conditions were never achieved during the constant-rate infusion since in both groups of patients the mean plasma concentrations of lignocaine rose pro-

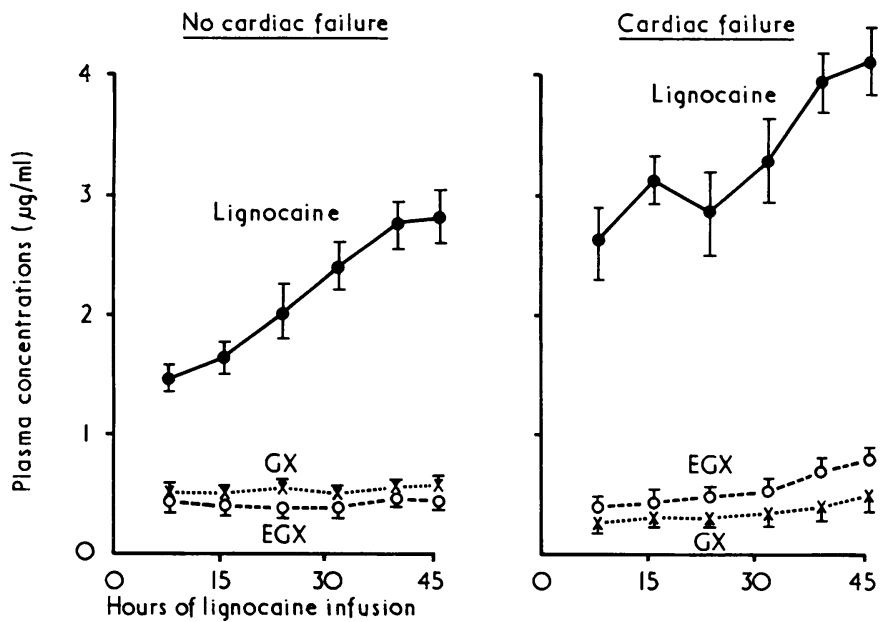

FIG 1-Mean plasma concentrations ( \pm SE of mean) of lignocaine, ethylglycylxylidide (EGX), and glycylxylidide (GX) in patients in coronary care unit with and without cardiac failure during constant infusion of lignocaine hydrochloride at $1.4 \mathrm{mg} / \mathrm{min}$. gressively, doubling in the patients without cardiac failure. When one patient (case 7) developed cardiogenic shock 25 hours after admission lignocaine concentrations rose from 2.9 to $6.5 \mu \mathrm{g} / \mathrm{ml}$ over 12 hours. In all patients the plasma concentrations of EGX and GX were much lower than those of the parent drug and never exceeded $1.0 \mu \mathrm{g} / \mathrm{ml}$. The concentrations of both metabolites rose progressively during the infusion in the patients with cardiac failure (fig 1).

After the infusion was discontinued the rate of disappearance of lignocaine, EGX, and GX from the plasma decreased progressively for about eight hours, after which it became exponential. The rate of fall was always slower in the patients with cardiac failure than in those without. Compared with healthy subjects, ${ }^{11}$ the mean terminal plasma half life values of lignocaine and EGX were greatly prolonged in both groups of patients, and the half life of GX was more than doubled in the presence of cardiac failure. Thus the mean lignocaine half life was prolonged from a normal value of 1.4 hours to 4.3 hours in patients without cardiac failure and to $10 \cdot 2$ hours in patients with cardiac failure (table II). The patient with cardiogenic shock appeared to be quite unable to eliminate lignocaine, EGX, and GX since the plasma concentrations of these compounds did not fall significantly when the infusion was stopped (fig 2).

TABLE II-Mean plasma half lives of lignocaine, EGX, and $G X( \pm S E$ of mean $)$ in healthy subjects ${ }^{11}$ and in patients with and without cardiac failure eight to 24 hours after discontinuing lignocaine infusion

\begin{tabular}{|c|c|c|c|}
\hline & \multicolumn{3}{|c|}{ Plasma half life (hours) } \\
\hline & Lignocaine & EGX & $G X$ \\
\hline $\begin{array}{l}\text { Healthy subjects } \\
\text { Patients without cardiac failure } \\
\text { Patients with cardiac failure }\end{array}$ & $\begin{array}{rl}1 \cdot 4 & \pm 0 \cdot 1 \\
4 \cdot 3 & \pm 0 \cdot 8 \\
10 \cdot 2 & 2 \cdot 0\end{array}$ & $\begin{array}{l}2 \cdot 3 \pm 0 \cdot 1 \\
6 \cdot 7 \pm 1 \cdot 3 \\
7 \cdot 8 \pm 1 \cdot 0\end{array}$ & $\begin{array}{c}17 \cdot 35^{*} \\
40 \cdot 4^{*}\end{array}$ \\
\hline
\end{tabular}

*Calculated from pooled data.

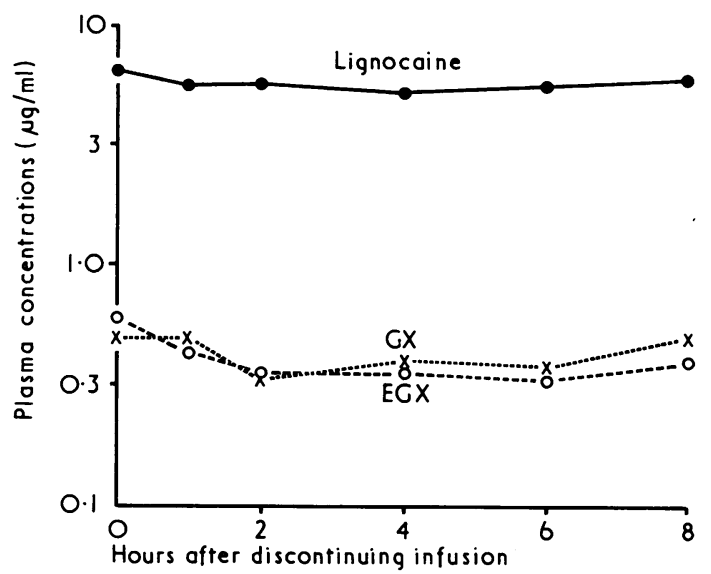

FIG 2-Failure of plasma concentrations of lignocaine, ethylglycylxylidide (EGX), and glycylxylidide (GX) to fall after discontinuing infusion in patient with cardiogenic shock.

\section{URINARY EXCRETION OF LIGNOCAINE AND ITS METABOLITES}

The pattern of urinary excretion of lignocaine and its metabolites was also consistent with impaired elimination of the drug, and during the first 48 hours the mean total amounts of drug and metabolites ( \pm SE of mean) excreted by the patients with and without cardiac failure were $34.9 \pm 7 \cdot 4 \%$ and $74 \cdot 1 \pm 2 \cdot 7 \%$ of the dose respectively. Over six days the patients with cardiac failure excreted more of the dose as unchanged lignocaine and EGX and less as GX and 4-hydroxyxylidine than those without cardiac failure (table III). These differences could not be accounted for by variation in urinary $\mathrm{pH}$ and flow rate.

\section{PLASMA ANTIPYRINE HALF LIFE}

The mean plasma antipyrine half lives on the second day in hospital and during convalescence are shown in table IV. The antipyrine half 
TABLE III-Urinary percentage recovery (means $\pm S E$ of mean) of administered dose of lignocaine in five patients with cardiac failure and six without cardiac failure in six days

\begin{tabular}{|c|c|c|c|c|c|}
\hline & Lignocaine & EGX & GX & 4-Hydroxyxylidine & Total \\
\hline $\begin{array}{l}\text { No cardiac failure } \\
\text { Cardiac failure }\end{array}$ & $\begin{array}{l}3 \cdot 5 \pm 0.4 \\
7 \cdot 8 \div 2 \cdot 1\end{array}$ & $\begin{array}{l}2.6 \pm 0.2 \\
7 \cdot 4 \pm 1.7\end{array}$ & $\begin{array}{l}3.2 \pm 0.4 \\
2.2 \pm 0.7\end{array}$ & $\begin{array}{l}69 \cdot 8 \pm 2 \cdot 3 \\
34 \cdot 3 \pm 6 \cdot 4\end{array}$ & $\begin{array}{l}79 \cdot 1 \pm 2 \cdot 7 \\
51 \cdot 7 \pm 10\end{array}$ \\
\hline
\end{tabular}

TABLE IV-Mean plasma antipyrine half lives ( $\pm S E$ of mean) measured on second day in hospital and during convalescence in patients with and without cardiac failure

\begin{tabular}{|c|c|c|}
\hline & \multicolumn{2}{|c|}{ Plasma antipyrine half life (hours) } \\
\hline & In hospital & During convalescence \\
\hline $\begin{array}{l}\text { Patients without cardiac failure } \\
\text { Patients with cardiac failure }\end{array}$ & $\begin{array}{l}12.2+0.6 \\
19.4+1.9\end{array}$ & $\begin{array}{r}9 \cdot 9 \pm 0 \cdot 7 \\
13 \cdot 2 \pm 1 \cdot 0\end{array}$ \\
\hline All patients & $16 \cdot 8: 1.4$ & $11 \cdot 8 \pm 0.7$ \\
\hline
\end{tabular}

life was significantly longer on the second hospital day than during convalescence and was significantly longer in the patients with cardiac failure than in those without. There were no significant differences in the apparent volumes of antipyrine distribution in any of the groups.

\section{Discussion}

Lignocaine is eliminated almost exclusively by metabolism in the liver and its removal from the plasma depends critically on hepatic blood flow since about $70^{\circ}$ o of the drug is normally extracted as it passes through the liver. ${ }^{2}{ }^{4}$ We found that lignocaine metabolism was significantly impaired after myocardial infarction and this impairment was even greater in patients with cardiac failure. The mean terminal plasma lignocaine half life of about 1.5 hours in healthy subjects ${ }^{11} 12$ was prolonged almost threefold in the patients with uncomplicated myocardial infarction while in those with cardiac failure it was increased to $10 \cdot 2$ hours. Plasma lignocaine concentrations during infusion were also always much higher in the patients with cardiac failure. Metabolism of the drug virtually ceased in the patient with cardiogenic shock as the plasma concentration rose rapidly and did not fall appreciably when the infusion was stopped. Although the patients with cardiac failure were older and weighed less than those without, this was unlikely to have accounted for the differences observed.

The considerable impairment of lignocaine metabolism in our patients was probably due largely to reduced liver blood flow associated with a low cardiac output. ${ }^{2}$ But other factors must also have contributed since the initial antipyrine half life was also prolonged, albeit not so much. The removal of antipyrine depends more on the liver's drug metabolising enzyme activity than on hepatic blood flow, as only about $3 \%$ is removed during one passage through the liver. ${ }^{13}$ In such a complex and unstable clinical condition it is difficult to elucidate the precise mechanisms at work, but stress, hypoxia, hepatic venous congestion, competitive inhibition caused by accumulation of lignocaine metabolites, and administration of other drugs may have reduced hepatic drug metabolising enzyme activity. Abnormal drug metabolism in patients with cardiac failure or myocardial infarction has been observed by some investigators ${ }^{2-5} 81415$ but not by others. ${ }^{1617}$ The choice of test drug is obviously very important since the metabolic clearance is probably reduced most with those drugs that have a high hepatic extraction ratio.

Another important but inexplicable observation in our study was the progressive increase in plasma lignocaine concentrations with failure to achieve constant "plateau" levels during the infusion in both groups of patients. Steady-state conditions are normally reached after about four half lives, which would be 15-20 hours in the patients without failure. In the concentrations observed in our study EGX and GX would seem to contribute little to antiarrhythmic activity or toxicity, although higher levels have been recorded. ${ }^{6} 14$

The practical implications of our findings are clear. When lignocaine was infused at the relatively slow rate of $1.4 \mathrm{mg} / \mathrm{min}$ plasma concentrations rose progressively to potentially toxic levels in some patients with cardiac failure. In such patients serious toxicity might be expected within a few hours at the rates of $4 \mathrm{mg} / \mathrm{min}, 8 \mathrm{mg} / \mathrm{min}$, or even $13 \mathrm{mg} / \mathrm{min}$ used by some investigators..$^{14} 1819$ No change is required in the initial loading dose of lignocaine in patients with cardiac failure, but to reduce the risk of toxicity it would be prudent to restrict the infusion rate to less than $2 \mathrm{mg} / \mathrm{min}$ and to halve the rate after 24 hours unless serious arrhythmias cannot be controlled. The drug clearly cannot be used safely in patients with cardiogenic shock unless plasma concentrations are monitored: severe, possibly fatal, toxicity would be inevitable within 12 hours at infusion rates of $4 \mathrm{mg} / \mathrm{min}$ or more. Furthermore, toxicity in such patients would probably be irreversible since the plasma concentrations of lignocaine did not fall when the infusion was stopped in our patient with cardiogenic shock. A fatal outcome in such circumstances would probably be attributed to myocardial infarction and shock rather than to lignocaine poisoning.

We gratefully acknowledge the assistance of the nursing and medical staff of the coronary care unit of the Edinburgh Roval Infirmary.

\section{References}

${ }^{1}$ Prescott, L F, Handbook of Experimental Pharmacology, ed O Eichler, et al, vol 28, part 3, p 234. Berlin, Springer Verlag, 1975.

2 Thomson, P D, et al, Annals of Internal Medicine, 1973, 78, 499.

3 Tokola, O, et al, British fournal of Clinical Pharmacology, 1975, 2, 429.

4. Stenson, R E, Constantino, R T, and Harrison, D C, Circulation, 1971, 43, 205.

${ }^{5}$ Prescott, L F, and Nimmo, J, in Lidocaine in the Treatment of Ventricular Arrhythmias, ed D B Scott and D G Julian, p 168. Edinburgh, Livingstone, 1971.

${ }^{6}$ Strong, J M, et al, Clinical Pharmacology and Therapeutics, 1975, 17, 184.

7 Strong, J M, Parker, M A, and Atkinson, A J, Clinical Pharmacology and Therapeutics, 1973, 14, 67.

8 Talbot, R G, et al, Lancet, 1973, 2, 399.

9 Adjepon-Yamoah, K K, and Prescott, L F, Fournal of Pharmacy and Pharmacology, 1974, 26, 889.

10 Prescott, L F, Adjepon-Yamoah, K K, and Roberts, M E, Fournal of Pharmacy and Pharmacology, 1973, 25, 205.

11 Adjepon-Yamoah, K K, Nimmo, J, and Prescott, L F, British Medical Fournal, 1974, 4, 387.

12 Boyes, R N, et al, Clinical Pharmacology and Therapeutics, 1971, 12, 105.

13 Prescott, L F, et al, fournal of Clinical Pathology, 1975, 28, Suppl 9, p 62.

14 Halkin, H, et al, Clinical Pharmacology and Therapeutics, 1975, 17, 669.

15 Sotaniemi, E A, et al, Clinical Pharmacology and Therapeutics, 1975, 17, 244.

16 Sadee, W, et al, European fournal of Clinical Pharmacology, 1974, 7, 195.

17 Kessler, K M, et al, New England fournal of Medicine, 1974, 290, 706.

${ }^{18}$ Ryden, L, et al, American Heart fournal, 1975, 89, 470.

19 Harrison, D C, and Alderman, E L, in Lidocaine in the Treatment of Ventricular Arrhythmias, ed D B Scott and D G Julian, p 178. Edinburgh, Livingstone, 1971. 